\title{
Sentimen Analisis Twitter Terhadap Isolasi Diri Masyarakat Indonesia Akibat Dampak Covid-19
}

\author{
Resi Taufan, Tri Rivanie, Sri Rahayu, Windu Gata
}

\begin{abstract}
The rise of the Corona or Covid-19 virus in Indonesia has resulted in the government recommending that Indonesian people carry out self-isolation and social distancing. This has caused many public responses, especially in the social media Twitter about these recommendations. In this research an analysis of community sentiment will be carried out on the impact felt by the community regarding self-isolation. There are several steps to do sentiment analysis, including the stages of data collection, data preprocessing, data validation and testing done with the rapidminer tool by using the TF-IDF feature to weight each word. In this study each tweet is classified into positive and negative sentiment. The Naive Bayes method in sentiment classification has a pretty good accuracy to classify sentiments.
\end{abstract}

Index Terms - Covid-19; Self Isolation; Sentiment Analyst; TF-IDF;

Abstrak-Maraknya penyebaran virus Corona atau Covid-19 di Indonesia mengakibatkan pemerintah menganjurkan agar masyarakat indonesia melakukan isolasi diri dan social distancing. Hal ini menyebabkan banyaknya tanggapan publik khusunya di media sosia twitter tentang anjuran tersebut. Dalam penelitan ini akan dilakukan analisis sentimen masyarakat terhadap dampak yang dirasakan masyarakat mengenai isolasi diri. Ada beberapa tahap untuk melakukan analisis sentimen, diantaranya adalah tahap pengumpulan data, preprocesing data, validasi data serta pengujian dilakukan dengan tools rapidminer dengan menggunakan fitur TF-IDF untuk melakukan pembobotan pada setiap kata. Pada penelitian ini setiap tweet diklasifikasikan menjadi sentiment positif dan negative. Metode Naive Bayes dalam klasifikasi sentimen memiliki akurasi yang cukup baik untuk melakukan klasifikasi sentimen.

Kata Kunci-Covid-19; Isolasi Diri; Sentimen Analisis; TF-IDF;

Resi Taufan, mahasiswa program studi Ilmu Komputer, STMIK Nusa Mandiri, email : resitauf1508@nusamandiri.ac.id.

Tri Rivanie, mahasiswa program studi Ilmu Komputer, STMIK Nusa Mandiri, email : 14002396@ nusamandiri.ac.id.

Sri Rahayu, dosen program studi Sistem Informasi, STMIK Nusa Mandiri, email : srirahayu.rry@nusamandiri.ac.id.

Windu Gata, dosen program studi Ilmu Komputer, STMIK Nusa Mandiri, email : windu@ nusamandiri.ac.id.

\section{PENDAHULUAN}

$\mathrm{B}$ elakangan ini masyarakat dunia diresahkan oleh Virus Corona atau Covid-19 yang penyebarannya termasuk paling besar dibandingkan dengan SARS (Severe Acute Respiratory Syndrome) dan Middle East respiratory syndrome coronavirus (MERS-CoV), sampai dengan kamis 12 Maret 2020 tercatat sudah menginfeksi 126.061 orang di 118 negara di dunia. Berdasarkan perhitungan situs pelaporan daring Worldometers, sekitar 67.064 orang dinyatakan sembuh dan 4.616 meninggal dunia (CNN Indonesia). Pemerintah Indonesia menganjurkan agar masayarkat untuk melakukan isolasi diri dan social distancing. Banyak masyarakat yang menanggapi kebijakan tersebut di sosial media dengan berbagai sentimen baik positif maupun negatif. Analisis sentimen atau opinion mining merupakan salah satu solusi mengatasi masalah untuk mengelompokan opini atau review menjadi opini positif atau negatif secara otomatis [1].

Penentuan polaritas positif atau negatifnya suatu opini dapat dilakukan secara manual, tetapi seiring bertambahnya sumber opini menjadi semakin banyak tentunya waktu dan usaha yang dibutuhkan untuk mengklasifikasikan polaritas opini tersebut akan semakin banyak terpakai. Oleh karena itu, diajukan penerapan metode pembelajaran mesin untuk mengklasifikasi polaritas opini dari sumber data yang sangat banyak tersebut. Untuk melakukan hal itu, bisa menggunakan salah satu fungsi dari text mining, dalam hal ini adalah klasifikasi dokumen [2].

Penggunaan media sosial seperti Facebook, Twitter, Pinterest, dan Youtube pada era abad informasi ini mengalami kenaikan yang sangat drastis dibandingkan dengan tahun - tahun sebelumnya. Data dari tahun 2015 saja memaparkan pengguna Twitter ada lebih dari 285 juta [3]. Meskipun begitu sebuah analisis teks tidak harus dengan media sosial tertentu, pemilihan pada media sosial Twitter, karena kelebihan Twitter memakai karakter dibawah 140, format pesan yang informal, teks pesan yang sangat banyak setiap harinya, berasal dari 
individu dengan latar belakang yang sangat bervariasi, dan mudah digunakan [4].

\section{LANDASAN TEORI}

Ada beragam teknik klasifikasi dokumen, di antaranya adalah Naive Bayes Classifier, Decision Trees, dan Support Vector Machines. Salah satu metode yang paling populer digunakan dalam pengklasifikasian dokumen sekarang ini adalah metode Naive Bayes Classifier [5]. Hal serupa juga diungkapkan oleh [6] dalam penelitiannya, yaitu metode Naive Bayes Classifier memiliki beberapa kelebihan antara lain, sederhana, cepat dan berakurasi tinggi.Penelitian mengenai analisis sentimen telah banyak dilakukan sebelumnya. Penelitian tetang analisis sentimen yang menggunakan dataset dari jejaring sosial Twitter dilakukan oleh [7]. Mereka melakukan analisis sentimen terhadap media jejaring sosial Twitter dengan menggunakan beberapa teknik klasifikasi. Penelitian sentimen analis dengan metode Nä̈ve bayes memiliki akurasi diatas $75 \%$ algoritma ini sering digunakan dalam analisis sentimen teks [8].

Selain metode Nä̈ve bayes pada analysis text mining dilakukakan pembobotan kata pada masing-masing tweet dengan memanfaatkan Term Frequency - Inverse Document Frequency (TF-IDF), Penerapkan TF-IDF untuk text mining sangat membantu pengguna. untuk mendapatkan informasi pada kumpulan dokumen. Dengan format file txt berdasarkan kata kunci yang dimasukan oleh pengguna pada system [9].

Penelitian selanjutnya yang menjadi acuan penulis dalam menyusun penelitian ini adalah penelitian yang dilakukan oleh [10]. Pada penelitian tersebut dilakukan analisis sentimen menggunakan metode naïve bayes dalam penentuan polaritas sentimen. Hasil dari peneltian tersebut menunjukkan akurasi yang cukup tinggi untuk metode Nä̈ve Bayes Classifier. Atas dasar hal ini, penulis bermaksud menerapkan metode Nä̈ve Nayes Classifier untuk melihat sentimen masyarakat di media Twitter terhadap isolasi diri akibat dampak dari covid-19.

\section{METODE PENELITIAN}

Rancangan penelitian dilkukan dengan proses data retrieval dari twitter sebanyak 525 tweet dengan query isolasi diri, kemudian dilakukan crowling dengan tools rapidminer.

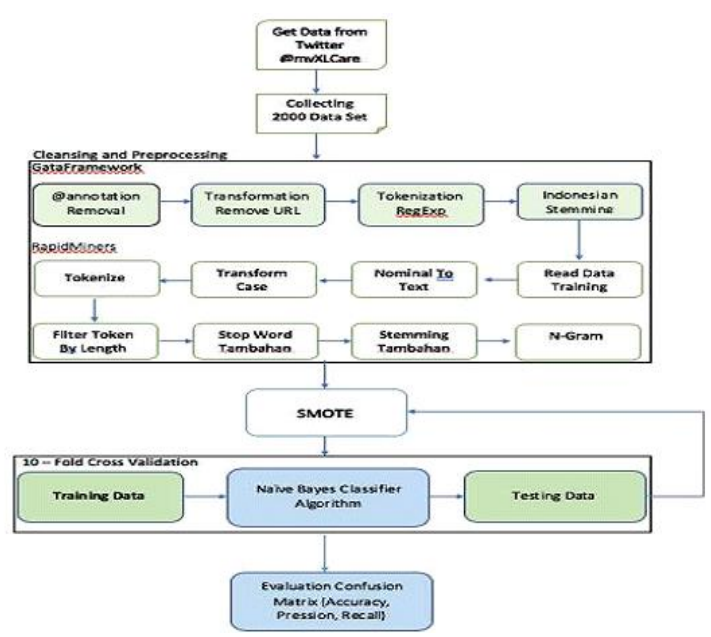

Gambar 1. Metodologi Penelitian Klasifikasi Sentimen Analis[10]

Pada penelitian ini rancangan yg dibangun hampir sama dengan penelitian sebelumnya [10] hanya saja prosess cleansing dan preprocessing dilakukan dengan rapidminer tidak dengan framework tambahan.

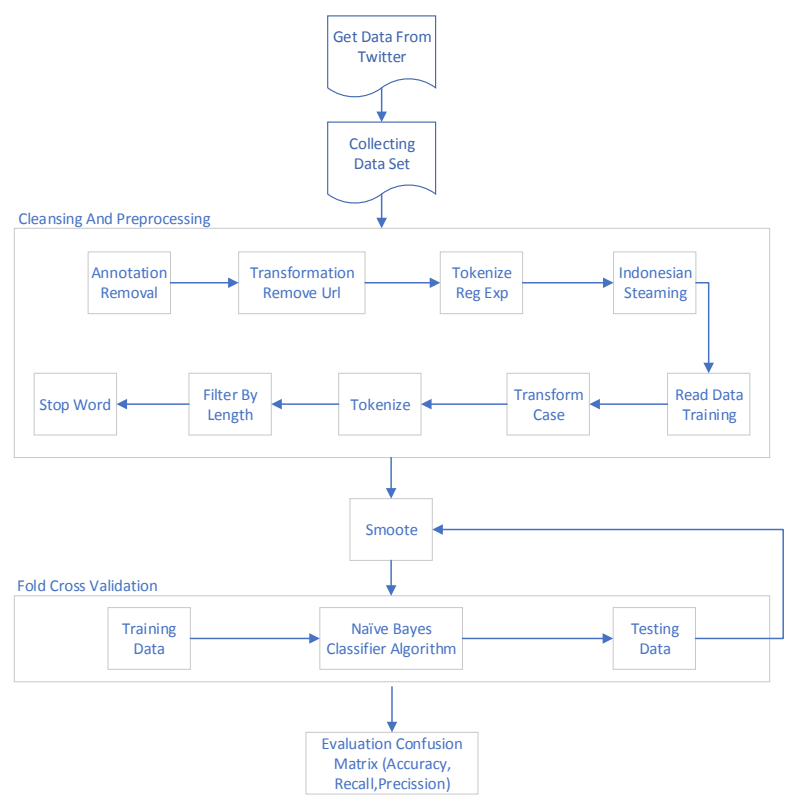

Gambar 2. Metodologi Penelitian Klasifikasi Sentimen Analis.

\section{HASIL DAN PEMBAHASAN}

Penelitian ini dimulai dari pengolahan data awal, preprocessing dan validasi. Berikut adalah tahapannya : a. Pengolahan Data Awal

Data yang digunakan pada penelitian bersumber dari twitter dengan cara mengkoneksikan raidminer dengan API twitter sebanyak 2000 tweet. Crawling data menggunkan aplikasi rapidminer dengan query 'Isolasi Diri'. Twitter memungkinka redudansi data dimana ada beberapa komentar yang di retweet sehingga perlu adanya Remove Duplicate, dari 2000 data terpilih 525 data unik atau tidak duplikat, kemudian dipilih data yang akan digunakan sebagai 
text, data ini berisi komentar positif dan negatif, setalelah itu dialkukan palebelan positif atau negatif pada setiap komentar.

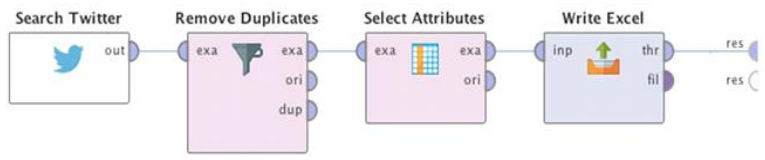

Gambar 3. Proses Data Retrieval dari Twitter[10]

\section{b. Preprocessing}

Tahapan ini merupakan tahap awal untuk mengolah data teks menjadi analisa sentimen. Proses dilanjutkan dengan menghitung probabilitas masing-masing kata dalam tweet berdasarkan data training menggunakan fitur TF-IDF. Berikut tahapan preprocessing yang digunakan :

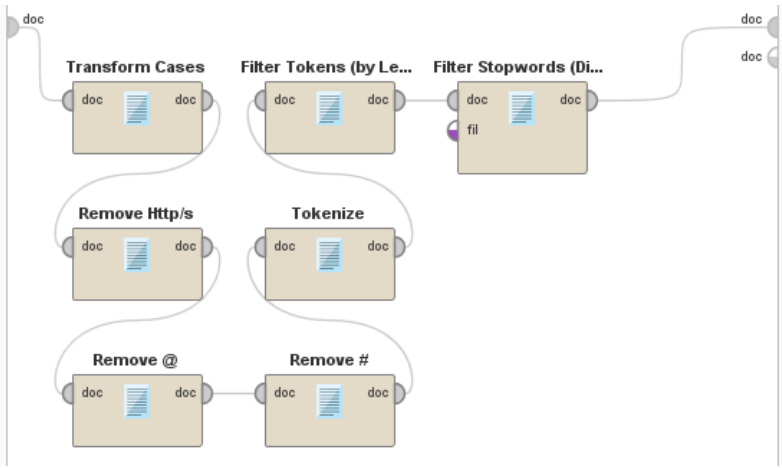

Gambar 4. Preprocessing pada tool rapidminer

\section{1) Transform Cases}

Pada proses ini, rapidminer akan mengubah kapitalisasi karakter (huruf) menjadi kecil untuk semua kata atau huruf. Seteleh melalui tahap ini, seluruh isi komentar akan menjadi non kapital.

Tabel 1. Hasil Transform cases

\begin{tabular}{|l|l|}
\hline Text & Transform Cases \\
\hline Berbelanja keperluan & berbelanja keperluan primer \\
primer untuk keperluan & untuk keperluan isolasi diri \\
isolasi diri hingga 2021 & hingga 2021 \\
https://t.co/UHqrR8z0yC & https://t.co/uhqrr8z0yc \\
\hline
\end{tabular}

\section{2) Tokenization}

Proses tokenization berfungsi untuk mengilangkan tanda baca, simbol dan karakter yang bukan berupa huruf pada setiap komentar. Proses tokenization pada peneltian ini seperti terlihat pada gambar 4 yaitu menghilangkan kata yang diawali http/https (Remove Http/s), menghilangkan karakter @ (Remove @) dan menghilangkan karakter \# (Remove \#).

Tabel 2. Hasil Tokenize

\begin{tabular}{|l|l|}
\hline Text & Tokenize \\
\hline$@$ null Tren Selebgram & @null Tren Selebgram Pamer \\
Pamer Isolasi Diri di & Isolasi Diri di Instagram, di \\
Instagram, di Bali Hingga & Bali Hingga Vila Mewah \\
\hline
\end{tabular}

\begin{tabular}{|c|c|}
\hline $\begin{array}{l}\text { Vila Mewah Banyak } \\
\text { https://t.co/6Sx1lgTpOC }\end{array}$ & Banyak \\
\hline $\begin{array}{l}\text { @ ganjarpranowo } \\
\text { Ngapunten pak, didesa } \\
\text { saya paklurahnya } \\
\text { menganjurkan untuk } \\
\text { isolasi diri dirumah selama } \\
14 \text { hari nanti setiap harinya } \\
\text { dipantau dari puskesmas. } \\
\text { Ngoten pak }\end{array}$ & $\begin{array}{l}\text { ganjarpranowo ngapunten } \\
\text { pak, didesa saya paklurahnya } \\
\text { menganjurkan untuk isolasi } \\
\text { diri dirumah selama } 14 \text { hari } \\
\text { nanti setiap harinya dipantau } \\
\text { dari puskesmas ngoten pak }\end{array}$ \\
\hline $\begin{array}{l}\text { Sejatinya pemerintah } \\
\text { setempat } \\
\text { menyediakan gudah } \\
\text { untuk mengisolasi diri, } \\
\text { namun dinilai tak layak. } \\
\text { \#publisherstory } \\
\text { https://t.co/iFsi2Jt3a2 }\end{array}$ & $\begin{array}{l}\text { sejatinya pemerintah setempat } \\
\text { sudah menyediakan gedung } \\
\text { untuk mengisolasi diri, } \\
\text { namun dinilai tak layak. } \\
\text { publisherstory }\end{array}$ \\
\hline
\end{tabular}

\section{3) Filter Token (by Length)}

Pada tahap ini dilakukan pemilihan token dengan ukuran panjang minimal 4 karakter (huruf), walaupun beberapa diantaranya adalah stopwords. Jika kata yang kurang dari 4 huruf namun termasuk dalam stopwords akan tetap dibuang, karena tahap selanjutnya adalah pembuangan stopwords. Proses filter token dapat dilihat pada Gambar 5.

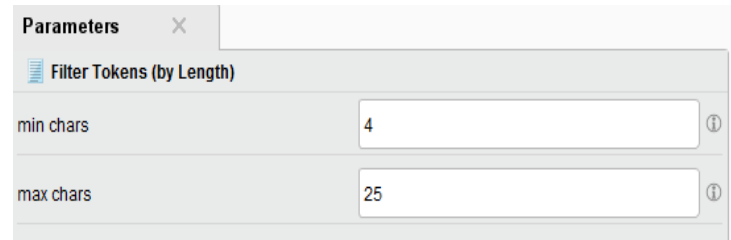

Gambar 5. Filter by length pada tool rapidminer

Tabel 3. Hasil filter token (by length)

\begin{tabular}{|l|l|}
\hline text & Filter Token (By Length) \\
\hline kgn bgt bro gmn kl & ketemu malem isolasi diri \\
kita ketemu nnt & \\
malem trs isolasi diri & \\
brg & \\
\hline
\end{tabular}

\section{4) Stopwords}

Pada tahap ini akan menyempurnakan tahap filter token by length. Kata-kata yang dibuang yaitu kata-kata yang tidak relevan seperti "untuk", "adalah", "sebuah", “oleh", “atau”, “pada”, "dalam", "sebagai", "menjadi”, “itu” dan sebagainya.

Tabel 4. Hasil Filter Token (By Length)
\begin{tabular}{|l|l|}
\hline text & Filter Token (By Length) \\
\hline Koruptor berada di Lapas & Koruptor berada Lapas \\
Sukamiskin orang yang & Sukamiskin melakukan \\
telah melakukan isolasi & isolasi diri paling sempurna \\
diri yang paling & ditengah wabah Covid -19, \\
sempurna ditengah wabah & sehat2 semua, paling hanya \\
Covid -19 saat ini, sehat2 & satu mereka tidak bisa \\
semua, paling hanya satu & piknik. \\
mereka tidak bisa piknik. & \\
\hline
\end{tabular}




\section{5) Stemming}

Pada tahap stemming, kata dengan kata hubung diubah menjadi kata dasar untuk tweet dalam bahasa Indonesia.

\section{c. Validasi}

Menguji dataset dengan komposisi data pengujian dan parameter pelatihan yang berbeda dilakukan dengan mendistribusikan data pelatihan dan menguji data dengan komposisi berdasarkan distribusi data dalam validasi silang $k$-fold dengan nilai $\mathrm{k}=2$ hingga $\mathrm{k}$ $=10$. Tes ini bertujuan untuk menentukan nilai $k$-fold optimal dalam proses klasifikasi opini dalam kasus penelitian ini.

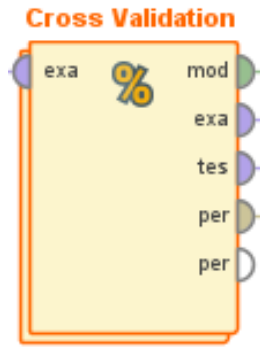

Gambar 6. Operator Cross validation $K$-fold

\section{d. Evaluasi}

Hasil dari implementasi model Naive Bayes tersebut akan didapat seluruh rule. Rule yang dihasilkan akan digunakan sebagai dasar prediksi nilai yang akan dilakukan. Sebelumnya rule tersebut harus dievaluasi dan divalidasi sehingga diketahui seberapa akurat hasil prediksi yang akan dilakukan. Pada tahap ini proses evaluasi menggunakan metode confusion matrix.

Model confusion matrix akan membentuk matriks yang terdiri dari accuracy, true positif dan true negatif, recall dan precision. Berikut merupakan hasil dari confusion matrix pada algoritma naive bayes classifier

\begin{tabular}{|l|l|l|l|}
\hline \multicolumn{2}{|c|}{ accuracy: $67.44 \%+/$ - $4.23 \%$ (micro average: $67.45 \%$ ) } & & \\
\hline & true Positif & true Negatif & $76.17 \%$ \\
\hline pred. Positif & 163 & 51 & $63.08 \%$ \\
\hline pred. Negatif & 158 & 270 & \\
\hline class recall & $50.78 \%$ & $84.11 \%$ & \\
\hline
\end{tabular}

Gambar 7. Accuracy, True Positif dan True Negatif, Recall dan Precision.

Hasil akurasi pengujian Naive Bayes untuk analisis sentimen pada media sosial twitter memperoleh hasil sebesar 67,44\% sedangkan untuk nilai AUC nya sebesar 0.477 yang dapat dilihat pada Gambar 8 .

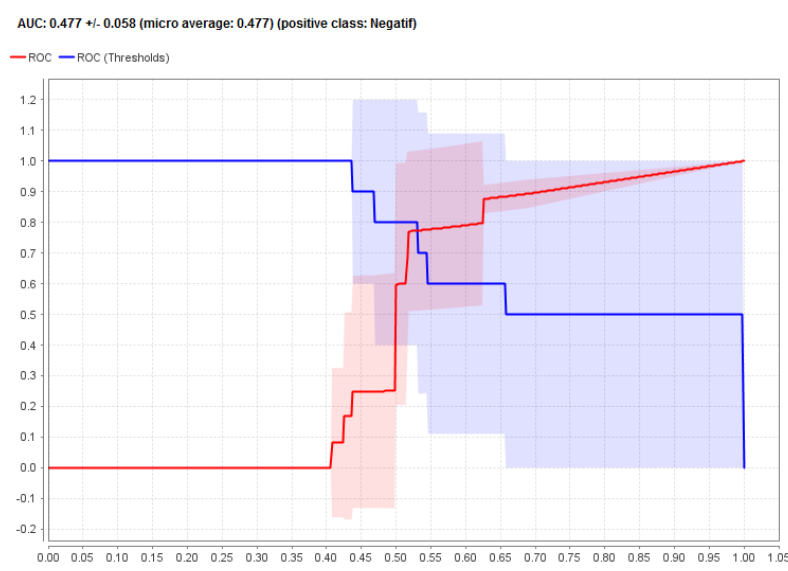

Gambar 8. AUC Process NBC

\section{KESIMPULAN}

Hasil analisa dalam penelitian ini penulis menyimpulkan bahwa sentimen masyarakat indonesia terhadap isolasi diri sebagai dampak dari Covid-19 dengan menggunakan metode Naive Bayes dan fitur TFIDF pada media sosial twitter menghasilkan akurasi yang cukup baik yaitu $67,44 \%$

\section{REFERENSI}

[1] E. Indrayuni, “Analisa Sentimen Review Hotel Menggunakan Algoritma Support Vector Machine Berbasis Particle Swarm Optimization,”vol. 4, 2016.

[2] F. Nurhuda and S. W. Sihwi, "Analisis Sentimen Masyarakat terhadap Calon Presiden Indonesia 2014 berdasarkan Opini dari Twitter Menggunakan Metode Naive Bayes Classifier," vol. 2, no. 2, 2014.

[3] S. Alim, "Analysis of tweets related to cyberbullying: Exploring information diffusion and advice available for cyberbullying victims," Int. J. Cyber Behav. Psychol. Learn., vol. 5, no. 4, pp. 31-52, 2015, doi: 10.4018/IJCBPL.2015100103.

[4] B. Pang and L. Lee, "Opinion Mining and Sentiment Analysis, " 2008.

[5] S. Natalius, "Makalah II2092 Probabilitas dan StatistikSem. I Tahun," no. 3, 2010.

[6] R. Mccue, "A Comparison of the Accuracy of Support Vector Machine and $\mathrm{Na}$ “" 1ve Bayes Algorithms In Spam Classification," pp. 1-17, 2009.

[7] R. Parikh and M. Movassate, "Sentiment Analysis of UserGenerated Twitter Updates using Various Classification Techniques," pp. 1-18, 2009.

[8] A. Fauzi, A. N. Rais, M. F. Akbar, and W. Gata, "ANALISIS SENTIMEN BERINTERNET PADA MEDIA SOSIAL NAIVE BAYES,” pp. 46-54, 2018.

[9] M. Nurjannah and I. Fitri Astuti, "PENERAPAN ALGORITMA TERM FREQUENCY-INVERSE DOCUMENT FREQUENCY (TF-IDF) UNTUK TEXT MINING Mahasiswa S1 Program Studi Ilmu Komputer FMIPA Universitas Mulawarman Dosen Program Studi Ilmu Komputer FMIPA Universitas Mulawarman," $J$. 
Inform. Mulawarman, vol. 8, no. 3, pp. 110-113, 2013.

[10] D. D. Saputra, W. Gata, N. K. Wardhani, and K. Sakho, "Optimization Sentiments of Analysis from Tweets in myXLCare using Naïve Bayes Algorithm and Synthetic Minority Over Sampling Technique Method Optimization Sentiments of Analysis from Tweets in myXLCare using Naïve Bayes Algorithm and Synthetic Minority Ov," 2020, doi: 10.1088/1742-6596/1471/1/012014. 